\title{
Cseresznyefák terméshozását és gyümölcsminőségét befolyásoló mütrágya kísérletek eredményei
}

\author{
${ }^{1 *}$ Csihon Ádám, ${ }^{1}$ GONDA István, ${ }^{2}$ Orosz-Tóth Mihály, \\ ${ }^{2}$ KINCSES Sándorné, ${ }^{1,3}$ HoLB Imre
}
${ }^{1}$ Debreceni Egyetem, Mezőgazdaság-, Élelmiszertudományi és Környezetgazdálkodási Kar, Kertészettudományi Intézet, Debrecen
${ }^{2}$ Debreceni Egyetem, Mezőgazdaság-, Élelmiszertudományi és Környezetgazdálkodási Kar, Agrokémiai és Talajtani Intézet, Debrecen
${ }^{3}$ MTA Agrártudományi Kutatóközpont Növényvédelmi Intézet, 1022 Budapest, Herman Ottó út 15.

\section{Bevezetés}

A cseresznye a mérsékelt égöv meghatározó gyümölcsfaja. Több mint 40 országban termesztik üzemi szinten, főként a 35. és az 55. szélességi fokok között, ahol az ökológiai adottságok kedvezőek eredményes müvelésükhöz (CHADHA, 2003). Termésmennyisége a világon 2018-ban elérte a 2,5 millió tonnát (FAO, 2020), amely az utóbbi években dinamikusan nö, köszönhetően a vásárlói igények növekedéséből adódó termőfelület gyarapodásának.

A cseresznye minőségét leginkább a gyümölcs mérete, színe, húskeménysége, aromája határozza meg (ESTI et al., 2002; SIMON et al., 2004; USENIK et al., 2005; MuSKOviCs et al., 2006; SZABÓ et al., 2011; GABRIELE et al., 2013; CSIHON et al., 2018). Emellett táplálkozás-élettani szempontból fontos értékmérő a tápelem-, a fenolos vegyület-, az antocianin-, és az antioxidáns-tartalma is (WANG at el., 1997; KIM et al., 2005; JAKOBEK at el., 2007). Figyelembe véve, hogy a cseresznye gazdag forrása a különböző flavonoidoknak, ásványi anyagoknak, vitaminoknak, gyümölcsének kereslete várhatóan tovább fokozódik (SWIETLIK, 2004). A hatóanyagok beépülése és mennyisége a gyümölcsbe azonban, jelentősen befolyásolt a tápanyag-utánpótlás mértékétől.

A tápanyag-gazdálkodás a termesztéstechnológia olyan része, amely szoros kapcsolatban van a növényvédelemmel, a metszéssel, a gyümölcsritkítással, és az öntözéssel. Továbbá alapvető fontosságú a növekedéshez és a jó állapotú gyümölcsfák neveléséhez (NAGY et al., 2010). A korszerủ tápanyag-utánpótlás fő célja egészséges, ízletes, jól színeződött és jól tárolható gyümölcsök előállítása a fogyasztók által elvárt mennyiségben és minőségben. A növénytáplálás javítása ezen célokat nagyban segíti, ugyanis a trágyázás számos módon befolyásolja a gyümölcs minőségét (NAGY et al., 2007, CsiHON et al., 2019).

A talajban a tápanyagok mennyisége befolyásolja a tápelemek gyümölcsbe jutását. A nagyobb mennyiségủ cukor-, és szerves savtartalom, valamint az optimális ásványi anyagtartalom jobb minőségú, és hosszabb tárolásra alkalmas gyümölcsöt eredményez (HUDINA \& STAMPAR, 2000). A cukor, valamint a szerves sav-tartalom nagyban függ a fajták és az ökológiai környezet sajátosságaitól, de jelentős hatása

*Levelezö szerző: CsIHON ÁDÁM, Debreceni Egyetem, Mezőgazdaság-, Élelmiszertudományi és Környezetgazdálkodási Kar, Kertészettudományi Intézet, 4002 Debrecen, Pf 400.

E-mail: csihonadam@agr.unideb.hu 
van a termesztéstechnológiai elemeknek is, mint az öntözés, a tápanyag-gazdálkodás, vagy a müvelés (HUDINA et al., 2003).

A cseresznye a legkorábban, kora nyáron érő fás szárú gyümölcsféle. A gyümölcs fejlődése mindössze 60-80 napot vesz igénybe a virágzástól a gyümölcsérésig, ami csupán egy két hetes, igen rövid sejtosztódási periódust foglal magában. Ebből kifolyólag rendkívül nagy jelentősége van, hogy a szükséges ásványi anyagok megfelelő időben és mennyiségben álljanak a cseresznyefák rendelkezésére (KAPPEL, 1991; SAN-MARTINO et al., 2008).

Munkánk során célul tüztük ki a különböző mütrágya kezelések (kontroll, NP, NPK, NPKMg) hatásának vizsgálatát a 'Carmen' cseresznyefajta termésmennyiségére és gyümölcsminöségére hároméves kísérlet eredményei alapján.

\section{Anyag és módszer}

Kísérleti beállításainkat a Debreceni Egyetem AKIT DTTI Pallagi Kertészeti Kísérleti Telepén végeztük a 2016-2018 között. A vizsgált ültetvény talajának fizikai félesége humuszos homok, Arany-féle kötöttségi száma 26-28 (1. táblázat). A humusztartalom a mélységtől függően 1,2-1,6\% között változik. A talaj kémhatása enyhén lúgos $(7,5-7,6 \mathrm{pH})$. A talaj $\mathrm{NO}_{3-}+\mathrm{NO}_{2-}-\mathrm{N}$ tartalma $3,0-5,1 \mathrm{mg} \mathrm{kg}^{-1} \mathrm{közötti,}$ ami az optimumnál $\left(8,0-10,0 \mathrm{mg} \mathrm{kg}^{-1}\right)$ kisebb. A foszfor, kálium és magnézium tartalomnál magasabb értékeket mértünk, mint ami a Mezőgazdasági Müszaki Irányelvek (MI 08-1741/1-88) alapján az optimális határérték $\left(\mathrm{P}_{2} \mathrm{O}_{5}: 80 \mathrm{mg} \mathrm{kg}^{-1}\right.$, $\mathrm{K}_{2} \mathrm{O}: 100-20 \mathrm{mg} \mathrm{kg}^{-1}$, Mg: $60 \mathrm{mg} \mathrm{kg}^{-1}$ ).

A talaj tápelem-tartalmának meghatározásánál szintén a Mezőgazdasági Müszaki Irányelvek (MI 08-1741/1-88) voltak irányadóak. A foszfor, kálium, kalcium és magnézium elemeknél az AL-oldható tartalmakat határoztuk meg (EGNER et al., 1960). $\mathrm{A} \mathrm{NO}_{3-}+\mathrm{NO}_{2-}-\mathrm{N}$ tartalom meghatározása SKALAR (1996) alapján történt. $\mathrm{A} \mathrm{CaCO}_{3}$ tartalmat a FILEP (1995) által leírt módszer szerint, Scheibler-féle kalciméter segítségével mértük meg.

1. táblázat

A kísérleti ültetvény talajának jellemzői (Debrecen-Pallag, 2016)

\begin{tabular}{|c|c|c|c|}
\hline & $0-20 \mathrm{~cm}$ & $20-40 \mathrm{~cm}$ & $40-60 \mathrm{~cm}$ \\
\hline Humusz-tartalom (\%)(1) & 1,6 & 1,5 & 1,2 \\
\hline Arany-féle kötöttségi szám (2) & 28 & 27 & 26 \\
\hline$p H$ & 7,6 & 7,6 & 7,5 \\
\hline $\mathrm{NO}_{3^{-}}+\mathrm{NO}_{2^{-}}-\mathrm{N}\left(\mathrm{mg} \mathrm{kg}^{-1}\right)$ & 3,0 & 5,1 & 4,4 \\
\hline$A L-P_{2} O_{5}\left(m g g^{-1}\right)$ & 146 & 95 & 83 \\
\hline$A L-K_{2} O\left(m g g^{-1}\right)$ & 351 & 330 & 301 \\
\hline$A L-M g\left(m g g^{-1}\right)$ & 108 & 97 & 145 \\
\hline $\mathrm{CaCO}_{3}(\mathrm{~m} / \mathrm{m}) \%$ & 0,33 & 0,35 & 0,21 \\
\hline
\end{tabular}


A kísérleti ültetvényt 2012 tavaszán telepítettük sajmeggy (Prunus mahaleb 'Cema') alanyon, 5 x 2,5 m térállásban. A vizsgált fajta a hazai nemesítésü 'Carmen'. Koronaformaként szabad orsót alakítottunk ki, amely magassága 3,5 méter. Az ültetvényben csepegtetö öntöző berendezés biztosítja a vízpótlást. A növényvédelemi technológia az integrált termesztési elveknek megfelelö.

A beállított kezeléseket a 2. táblázat foglalja össze. A nitrogén, foszfor, kálium és magnézium hatóanyag-tartalmú készítményeket első alkalommal 2016 tavaszán juttattuk ki a gyümölcsösbe. A későbbiekben a trágyázás megosztva történt, a P-, a $\mathrm{K}$-, és a Mg-tartalmú trágyákat ősszel, míg a N-tartalmút tavasszal szórtuk ki. A trágyázási időpontokat a 3. táblázat tartalmazza.

A nitrogén hatóanyagot pétisó formájában $(27 \% \mathrm{~N}, 7 \% \mathrm{CaO}, 5 \% \mathrm{MgO})$, a foszfort szuperfoszfátként $\left(18 \% \mathrm{P}_{2} \mathrm{O}_{5}\right)$, a káliumot kálisóként $\left(60 \% \mathrm{~K}_{2} \mathrm{O}\right)$, a magnéziumot pedig Kieserit ( $25 \% \mathrm{MgO}, 20 \%$ S) készítmény formájában juttattuk ki. A kiadagolt mütrágyát sekélyen dolgoztuk a talajba.

\section{2. táblázat}

A mütrágya kezelések (Debrecen-Pallag, 2016-2018)

\begin{tabular}{|l|c|c|c|c|}
\hline & $\begin{array}{c}\boldsymbol{N} \\
\left(\mathbf{k g ~ h a} a^{-1}\right)\end{array}$ & $\begin{array}{c}\boldsymbol{P}_{2} \mathrm{O}_{5} \\
\left(\mathrm{~kg} \mathrm{ha}^{-1}\right)\end{array}$ & $\begin{array}{c}\boldsymbol{K}_{2} \mathrm{O} \\
\left(\mathrm{kg} \mathrm{ha}^{-1}\right)\end{array}$ & $\begin{array}{c}\mathbf{M g O} \\
\left.(\mathbf{k g ~ h a})^{-1}\right)\end{array}$ \\
\hline Kontroll (1) & 0 & 0 & 0 & 0 \\
\hline $\boldsymbol{N}+\boldsymbol{P}$ & 60 & 80 & 0 & 0 \\
\hline $\boldsymbol{N}+\boldsymbol{P}+\boldsymbol{K}$ & 60 & 80 & 100 & 0 \\
\hline $\boldsymbol{N}+\boldsymbol{P}+\boldsymbol{K}+\boldsymbol{M g}$ & 60 & 80 & 100 & 30 \\
\hline
\end{tabular}

3. táblázat

A műtrágyák kijuttatásának időpontjai (Debrecen-Pallag, 2016-2018)

\begin{tabular}{|l|l|}
\hline Trágyázás időpontja (1) & Kijuttatott tápelemek (2) \\
\hline 2016.04 .07$. & $\mathrm{N}, \mathrm{P}, \mathrm{K}, \mathrm{Mg}$ \\
\hline 2016.11 .16$. & $\mathrm{P}, \mathrm{K}, \mathrm{Mg}$ \\
\hline 2017.03 .22$. & $\mathrm{N}$ \\
\hline 2017.11 .15$. & $\mathrm{P}, \mathrm{K}, \mathrm{Mg}$ \\
\hline 2018.03 .29$. & $\mathrm{N}$ \\
\hline 2018.11 .14$. & $\mathrm{P}, \mathrm{K}, \mathrm{Mg}$ \\
\hline
\end{tabular}

Vizsgált paraméterek

Az adatfelvételezések céljára kezelésenként és fajtánként 5-5 azonos termetủ és állapotú fa került kiválasztásra. 
Termésmennyiség $(\mathrm{kg} / f a)$, fajlagos termésmennyiség $\left(\mathrm{kg} \mathrm{cm}^{-2}\right)$

A gyümölcsök betakarításakor megmértük a fák termésmennyiségét $(\mathrm{kg} / \mathrm{fa})$. Értékét később a törzs-keresztmetszetre számítottuk át $\left(\mathrm{kg} \mathrm{cm}^{-2}\right)$ az objektív összehasonlíthatóság érdekében.

Gyümölcsméret (mm)

Fánként $20 \mathrm{db}$, kezelésenként $100 \mathrm{db}$ gyümölcs alapján digitális tolómérö segítségével meghatároztuk azok méretét $(\mathrm{mm})$.

Gyümölcsök szárazanyag-tartalma ( $\mathrm{m} / \mathrm{m} \%)$, vizoldható szárazanyag-tartalma (BRIX\%)

A szárazanyag-tartalom vizsgálata szárítószekrényben szárítással, a vízoldható szárazanyag-tartalom ATAGO refraktométerrel történt.

Gyümölcsök sav-tartalma (m/m\%) (MSZ ISO 750:2001)

A megfelelően előkészített terméket homogenizáljuk, bemérünk $25 \mathrm{~g}$ mennyiséget és $50 \mathrm{ml}$ forró vizet, majd vízfürdőn tartjuk 30 percig, szürjük, titráljuk. Titrálás $0,1 \mathrm{M} \mathrm{NaOH}$-mérőoldattal, fenolftalein indikátor jelenlétében. Ha a szín zavaros, akkor potenciometriásan $\mathrm{pH}=8,1$-ig titráljuk.

Gyümölcsök elemtartalma ( $P, K, M g$ )

A megfelelően előkészített (aprított, homogenizált) mintából 1,0000 g-ot roncsoló csövekbe mértünk be. Az elöroncsolás során $10 \mathrm{ml}$ desztillált cc. $\mathrm{HNO}_{3}$-at adagolunk a mintára és $60^{\circ} \mathrm{C}$-on 30 percig melegítettük elektromos blokkroncsolón (LABOR MIM), majd hagytuk lehülni. Ezt követően $3 \mathrm{ml}$ 30\%-os nagytisztaságú $\mathrm{H}_{2} \mathrm{O}_{2}$-t adunk a roncsolmányhoz és 90 percig $120^{\circ} \mathrm{C}$-on tartottuk. A roncsolmány lehülése után azt 50 ml-re töltöttük ioncserélt vízzel és MN 640W (Macherey-Nagel) szűrőpapíron keresztül szürtük. Az elemtartalom meghatározását a roncsolmányokból Optima 3300 DV ICP-OES (Perkin-Elmer) készüléken végeztük.

\section{Statisztikai értékelés}

$\mathrm{Az}$ eredmények értékeléséhez egytényezős varianciaanalízist (ANOVA) alkalmaztunk $(\mathrm{p}<0,05)$. A gyümölcsméret bemutatásánál az oszlopdiagramokon az oszlopok magassága a mért értékek átlagát, a vonalak a szórást jelentik.

\section{Eredmények és azok értékelése}

A fánkénti termésmennyiséget, amit a kezelések mellett az évjárati hatások és a fák életkora is befolyásolt, a 4. táblázatban mutatjuk be. 2016-ban, a termőre fordult, ötéves korú fákon 5,9-11,3 kg gyümölcs termett. 2017-ben a tavaszi fagyoknak köszönhetöen a hatéves korú fákon a termésmennyiség érdemben nem növekedett (7,2-9,0 kg/fa), egyes kezeléseknél csökkent. A 2018-as év a cseresznyetermesztés 
szempontjából kedvező évjáratnak bizonyult, a termésmennyiség 14,4-30,1kg/fa között változott.

A mütrágya kezeléseket tekintve elmondható, hogy mindhárom vizsgálati évben, valamennyi kezelés nagyobb termésmennyiséget eredményezett, mint a kontroll. A legmagasabb hozamokat 2018-ban az NP és NPK kezelésnél mértük $(28,1-30,1 \mathrm{~kg} / \mathrm{fa})$. A kezeletlen fák hozama minden évben a legalacsonyabb volt $(5,9-14,4 \mathrm{~kg} / \mathrm{fa})$.

A fajlagos, azaz a törzsvastagsághoz viszonyított termésadatoknál hasonló tendencia rajzolódik ki, a műtrágyázott fák termésmennyisége meghaladta a kezeletlen fákét. Statisztikailag igazolható különbség 2016-ban a kontrollhoz (94 $\left.\mathrm{g} \mathrm{cm}^{-2}\right)$ képest az NP $\left(175 \mathrm{~g} \mathrm{~cm}^{-2}\right)$ és NPKMg $\left(180 \mathrm{~g} \mathrm{~cm}^{-2}\right)$ kezelésnél, 2017-ben pedig az NPKMg $\left(115 \mathrm{~g} \mathrm{~cm}^{-2}\right)$ kezelésnél látható. A három év átlagát tekintve az NP $\left(166 \mathrm{~g} \mathrm{~cm}^{-2}\right)$ és az NPKMg $\left(163 \mathrm{~g} \mathrm{~cm}^{-2}\right)$ kezelés mutatott igazolható különbséget a kontrollhoz viszonyítva $\left(120 \mathrm{~g} \mathrm{~cm}^{-2}\right)$.

4. táblázat

A termésmennyiség alakulására a kezelések hatására (Debrecen - Pallag, 2016-2018)

\begin{tabular}{|l|c|c|c|c|c|c|c|c|}
\hline & \multicolumn{4}{|c|}{$\begin{array}{c}\text { Termésmennyiség } \\
(\mathbf{k g} / \mathbf{f a})(1)\end{array}$} & \multicolumn{3}{c|}{$\begin{array}{c}\text { Fajlagos termésmennyiség } \\
\left(\mathbf{g ~ c m}^{-2}\right)(2)\end{array}$} \\
\hline & $\mathbf{2 0 1 6}$ & $\mathbf{2 0 1 7}$ & $\mathbf{2 0 1 8}$ & $\begin{array}{c}\text { Három } \\
\text { év átlaga } \\
(3)\end{array}$ & $\mathbf{2 0 1 6}$ & $\mathbf{2 0 1 7}$ & $\mathbf{2 0 1 8}$ & $\begin{array}{c}\text { Három } \\
\text { év átlaga } \\
(3)\end{array}$ \\
\hline Kontroll & $5,9 \mathrm{a}$ & $7,2 \mathrm{a}$ & $14,4 \mathrm{a}$ & $9,1 \mathrm{a}$ & $94 \mathrm{a}$ & $79 \mathrm{a}$ & $186 \mathrm{a}$ & $120 \mathrm{a}$ \\
\hline NP & $11,3 \mathrm{~b}$ & $8,3 \mathrm{a}$ & $30,1 \mathrm{c}$ & $16,6 \mathrm{c}$ & $175 \mathrm{~b}$ & $73 \mathrm{a}$ & $249 \mathrm{a}$ & $166 \mathrm{~b}$ \\
\hline NPK & $9,5 \mathrm{a}$ & $8,5 \mathrm{a}$ & $28,1 \mathrm{c}$ & $15,4 \mathrm{c}$ & $152 \mathrm{a}$ & $93 \mathrm{a}$ & $208 \mathrm{a}$ & $151 \mathrm{a}$ \\
\hline NPKMg & $7,8 \mathrm{a}$ & $9,0 \mathrm{a}$ & $18,6 \mathrm{~b}$ & $11,8 \mathrm{~b}$ & $180 \mathrm{~b}$ & $115 \mathrm{a}$ & $193 \mathrm{a}$ & $163 \mathrm{~b}$ \\
\hline SzD5\% & 3,9 & 4,0 & 2,9 & 2,0 & 72 & 47 & 99 & 43 \\
\hline
\end{tabular}

A cseresznyére vonatkozó minőségi előírások alapján a friss piaci értékesítéshez 26 mm-es átmérő elérése kívánatos. A 'Carmen' fajta az egyik legnagyobb gyümölcsmérettel rendelkezö hazai fajta, minden évben teljesítette az elvártakat. A 2016-os, legalacsonyabb termésmennyiségủ évben a prémiumnak számító 32-34 mm-es átmérőt is elérték a gyümölcsök (1. ábra). 2017-ben 31-33 mm-es, 2018-ban pedig 27,5-30 mm-es gyümölcsöket takarítottunk be. A leglátványosabb különbség az utóbbi évben alakult ki, a mütrágyázott fák termései $30 \mathrm{~mm}$-esek, míg a kontroll kezelésé 2,5 mm-el kisebbek, ami a cseresznye esetében jelentősnek mondható. A 2017-es évben az NP és az NPKMg kezelésnél érte el a különbség az 1 mm-t a kontrollhoz képest. Adott éven belül a különböző hatóanyagú mütrágya kezelések között következetes különbséget nem eredményeztek a gyümölcsméretben. 


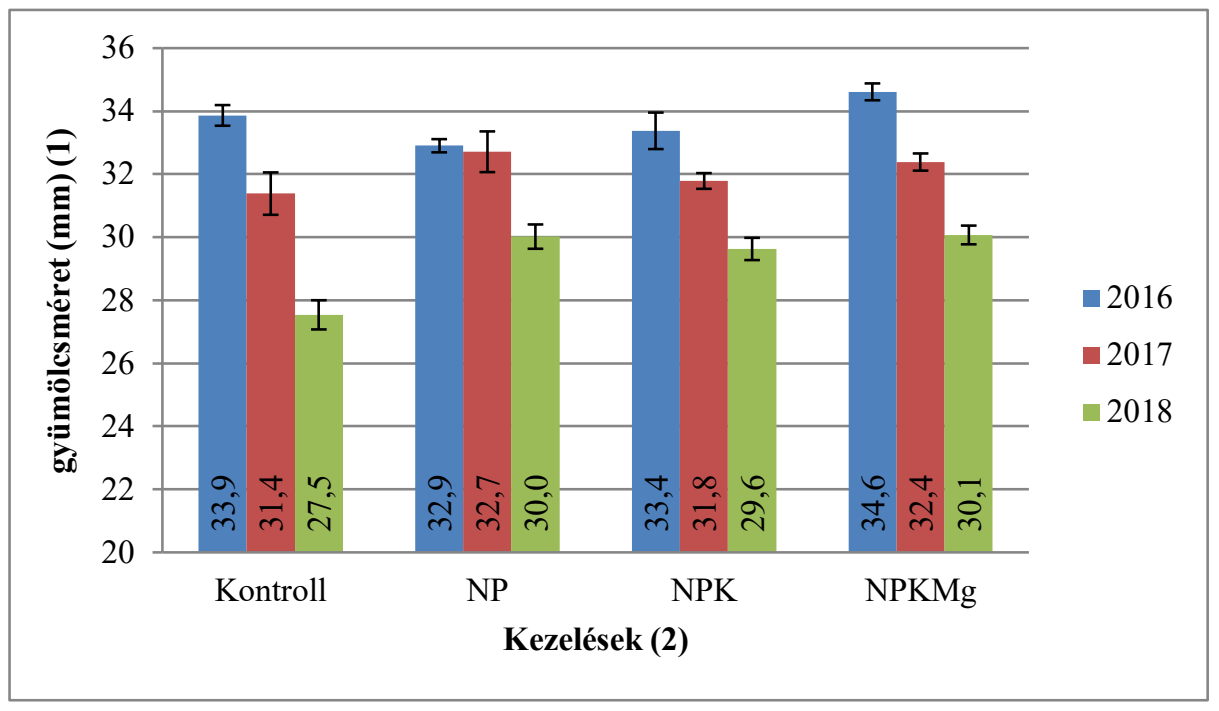

1. ábra

A gyümölcsméret alakulása a kezelések hatására (Debrecen-Pallag, 2016-2018)

A gyümölcsök beltartalmi paramétereit az 5. táblázat foglalja össze. A szárazanyag-tartalom $(\mathrm{m} / \mathrm{m} \%)$, valamint vízoldható szárazanyag-tartalom (BRIX\%) a mütrágya kezelésben részesült fákon a 2016-2017-es években csökkent, míg 2018-ban nőtt a kontrollhoz viszonyítva. 2016-ban az NP, NPK és NPKMg kezeléseknél 14,6-15,4 $\mathrm{m} / \mathrm{m} \%$ értékeket mértünk, míg a kontroll esetében 17,1 m/m\%-ot. 2017-ben ez a kezelt fákon 16,6-16,8 m/m\% közötti, míg a kontrollnál 17,4 m/m\%. 2018-ban ezzel ellentétes eredményeket kaptunk, a trágyázott fák gyümölcsei nagyobb szárazanyag-tartalommal rendelkeztek $(14,8-15,1 \mathrm{~m} / \mathrm{m} \%)$, mint a kontroll $(14,2 \mathrm{~m} / \mathrm{m} \%)$. A vízoldható szárazanyag-tartalomnál a mütrágyázott fák közül a legmagasabb értékeket 2017-ben és 2018-ban az NPK és NPKMg kezelésnél mértük (15,3-15,4 BRIX\%, illetve 14,5 BRIX\%).

A savtartalom 2017-ben és 2018-ban valamennyi kezelésnél meghaladta a kontroll értékeit. 2017-ben 11,0-13,1\%-al, míg 2018-ban 4,5-12,8\%-al kaptunk magasabb értékeket az NP, NPK és NPKMg kezeléseknél. A mütrágyás kezeléseket tekintve a legmagasabb savtartalmat mindhárom évben az NPK kezelésnél $(0,563 \mathrm{~m} / \mathrm{m} \%, 0,794 \mathrm{~m} / \mathrm{m} \%, 0,654 \mathrm{~m} / \mathrm{m} \%)$ mértük. Figyelembe véve a vízoldható szárazanyag-tartalom alakulását is, a legjobb gyümölcsminőséget beltartalmi szempontból 2017-ben kaptuk, amikor a magasabb savtartalom mellé magasabb $\mathrm{BRIX} \%$ is párosult.

A gyümölcsök tápelem tartalmánál az első évben jelentősebb változást nem eredményeztek a kezelések, 2017-2018-ban viszont egyértelmüen javult a gyümölcsök elemtartalma. A foszfor mennyisége 2017-ben 16-22\%-al (115-121 $\mathrm{mg} \mathrm{kg}{ }^{-1}$ ), 2018-ban pedig ennél is markánsabban, 57-70\%-al növekedett (132-143 
mg kg-1) a kontrollhoz képest ( $99 \mathrm{mg} \mathrm{kg}^{-1}$, illetve $84 \mathrm{mg} \mathrm{kg}^{-1}$ ). A kálium tartalomnál 2017-ben 4-18\%-os (1753-2002 mg kg-1), míg 2018-ban 13-22\%-os (2040-2195 mg $\left.\mathrm{kg}^{-1}\right)$ növekedés látható a kezeletlen fákhoz viszonyítva $\left(1693 \mathrm{mg} \mathrm{kg}^{-1}\right.$, illetve 1805 $\mathrm{mg} \mathrm{kg}^{-1}$ ). A gyümölcsök magnézium tartalma ugyancsak magasabb volt 2017-ben 12-20\%-al (55-59 mg kg-1), 2018-ban 21-43\%-al (47-49 $\left.\mathrm{mg} \mathrm{kg}^{-1}\right)$.

\section{5. táblázat}

A gyümölcsök beltartalmi paramétereinek alakulása a kezelések hatására (Debrecen-Pallag, 2016-2018)

\begin{tabular}{|c|c|c|c|c|c|c|c|c|c|c|c|c|}
\hline & \multicolumn{4}{|c|}{2016} & \multicolumn{4}{|c|}{2017} & \multicolumn{4}{|c|}{2018} \\
\hline & $\varnothing$ & NP & NPK & NPKMg & $\varnothing$ & NP & NPK & NPKMg & $\varnothing$ & NP & NPK & NPKMg \\
\hline $\begin{array}{l}\text { Sz. } \\
\text { anyag- } \\
\text { tartalom } \\
(\mathbf{m} / \mathbf{m}) \\
\%(1) \\
\%\end{array}$ & 17,1 & 14,9 & 15,4 & 14,6 & 17,4 & 16,6 & 16,8 & 16,7 & 14,2 & 14,8 & 15,2 & 15,1 \\
\hline BRIX\% & 15,3 & 13,0 & 13,7 & 12,8 & 16,5 & 15,1 & 15,3 & 15,4 & 13,5 & 14,0 & 14,5 & 14,5 \\
\hline $\begin{array}{l}\text { Sav- } \\
\text { tartalom } \\
(\mathbf{m} / \mathbf{m}) \\
\%(2) \\
\end{array}$ & 0,511 & 0,544 & 0,563 & 0,477 & 0,702 & 0,793 & 0,794 & 0,779 & 0,580 & 0,606 & 0,654 & 0,638 \\
\hline $\begin{array}{l}P(\mathbf{m g} \\
\left.\mathrm{kg}^{-1}\right)\end{array}$ & 217 & 201 & 192 & 218 & 99 & 115 & 121 & 119 & 84 & 132 & 143 & 136 \\
\hline $\begin{array}{l}\mathrm{K}(\mathrm{mg} \\
\left.\mathrm{kg}^{-1}\right) \\
\end{array}$ & 1795 & 1590 & 1670 & 1845 & 1693 & 1863 & 1753 & 2002 & 1805 & 2040 & 2195 & 2151 \\
\hline $\begin{array}{l}\mathrm{Mg}(\mathrm{mg} \\
\left.\mathrm{kg}^{-1}\right)\end{array}$ & 126 & 116 & 122 & 123 & 49,2 & 55,3 & 58,5 & 57,9 & 38,9 & 47,5 & 55,7 & 49,4 \\
\hline
\end{tabular}

\section{Következtetések}

Munkánk során különbözö műtrágyakezelések hatását vizsgáltuk 'Carmen' fajtájú intenzív cseresznyeültetvényben. Megfigyeléseink alapján látható, hogy a kísérlet tartamjellege ellenére már a hároméves eredményekben is jól megmutatkozott a kezelések hatása. A mütrágyázott fák termésmennyisége nőtt, gyümölcsminősége és beltartalma egyértelmüen javult a kontroll fákéhoz képest. A mütrágya kezelésben három éve nem részesülő cseresznyefákon a kondícióromlás tehát jelentős mennyiségi és minőségi veszteséget eredményezett. A különböző tápelemeket tartalmazó kezelések között szignifikáns különbség a legtöbb mért paraméter között nem mutatkozott. Ezek a fák évelö jellegéböl is adódóan vélhetően hosszabbtávon jelennek meg. Eredményeink felhívják a figyelmet arra, hogy az intenzív cseresznyetermesztés középerös növekedési erélyü alanyokon (Prunus mahaleb 'Cema') sem nélkülözheti az évenkénti, szakszerü tápanyag-utánpótlást. Ennek hiányában ugyanis jelentősen csökken a fák vegetatív és generatív teljesítménye. 


\section{Összefoglalás}

A növénytáplálás jelentősen befolyásolja a gyümölcsültetvényekben elérhető termés mennyiségét és minőségét. Hároméves kísérletünkben (2016-2018) különbözö mütrágya kezelések hatását hasonlítottuk össze egy sajmeggy alanyú, 'Carmen' fajtájú, szabad orsó koronájú intenzív cseresznyeültetvényben. Az NP, NPK és NPKMg kezeléseknél a fánkénti termésmennyiség a három év átlagában 11,8-16,6 kg/fa között változott, míg a kontrollnál ez 9,1 kg/fa mennyiség volt. A fajlagos, azaz a törzs vastagságához viszonyított termésmennyiségnél $151-166 \mathrm{~g} \mathrm{~cm}^{-2}$ közötti értékeket rögzítettünk, míg a kezeletlen fáknál $120 \mathrm{~g} \mathrm{~cm}^{-2}$-t. A mütrágyázott fák termései 2018-ban $30 \mathrm{~mm}$-esek, míg a kontroll kezelésé 2,5 mmel kisebbek voltak. A gyümölcsök vízoldható szárazanyag-tartalma (BRIX\%) a mütrágya kezelésben részesült fákon a 2016-2017-es években csökkent, míg 2018-ban nőtt a kontrollhoz viszonyítva. A tápelem tartalom esetében 2017-2018ban a foszfornál 16-70\%-os, a káliumnál 4-22\%-os, míg a magnéziumnál $12-43 \%$ os növekedést tapasztaltunk.

Kulcsszavak: cseresznye, termésmennyiség, gyümölcsminőség, tápanyaggazdálkodás

\section{Köszönetnyilvánítás}

'Köszönettel tartozunk a Debreceni Egyetem AKIT DTTI Pallagi Kertészeti Kísérleti Telep dolgozóinak a vizsgálatok kivitelezésében nyújtott segítségért. A dolgozat elkészítését az EFOP 3.6.1-16-2016-00022 számú projekt valamint az OTKA K 131478 projekt is támogatta. A projekt az Európai Unió támogatásával, az Európai Szociális Alap társfinanszírozásával valósult meg. A tanulmány alapjául szolgáló kutatást az Innovációs és Technológiai Minisztérium által meghirdetett Tématerületi Kiválósági Program ED_18-1-2019-0028 számon támogatta.'

\section{Irodalomjegyzék}

CHADHA, K. L. (2003). Cherry. In: Handbook of horticulture (ed. K. L. CHADHA). Delhi, India: Directorate of Information and Publications of Agriculture. Indian Council of Agricultural Research. pp. 161-166.

Csimon, Á., BiCsKeI, D. K., DremÁK, P., GondA, I. (2018). Performance of sweet cherry cultivars grafted on Colt rootstock. International Journal of Horticultural Science. 24. (1-2) 7-10.

CSIHON, Á., GONDA, I., OROSZ-TóTH, M., KINCSES, S.-NÉ., HOLB, I. (2019): N, P, K és Mg mütrágyák hatásának értékelése 'Golden Reinders' almafajta növekedési és termés tulajdonságaira. Agrokémia és Talajtan. 68. (2) 279-292.

EGNÉR, H., RIEHM, H., DOMINGO, W. R. (1960). Untersuchungen über die chemische Bodenanalyseals Grundlage für die Beurteilung de Nährstoffzustandes der Böden. II. K. Lantbruks-Högskolans Annalar. 26. 199-215. 
Cseresznyefák terméshozását és gyümölcsminőségét befolyásoló mütrágya kísérletek... 51

Esti, M., Cinquanta, L., Sinesio, F., Moneta, E., Mateo, M. D. (2002). Physicochemical and sensory fruit characteristics of two sweet cherry cultivars after cool storage. Food Chemistry. 76. 399-405. p.

FAO (2020). http://www.fao.org/faostat/en/\#data/QC. Letöltve: 2020.05.20.

FILEP, G. (1995). Talajvizsgálat. Debreceni Agrártudományi Egyetem Mezőgazdaságtudományi Kar Talajtani és Mikrobiológiai Tanszék, Debrecen, 77-79. p.

Gabriele, B., Continella, A., Gentile, A., Amenta, M., Fabroni, S., RAPISARDA, P. (2013). Fruit quality and bioactive compunds relevant to human health of sweet cherry (Prunus avium L.) cultivars grown in Italy. Food Chemistry 140. 630-638.

HUDINA, M., STAMPAR, F. (2000). Influence of water regimes and mineral contents in soil upon the contents of minerals, sugars and organic acids in pear fruits (Pyrus communis L.) cv. 'Williams'. Phyton 40. 91-96.

HudinA, M., SOlAR, A., STAMPAR, F. (2003). Does foliar nutrition influence the pear fruit quality? International Journal of Horticultural Science. 9. (2) 25-28.

JakobeK, L., Seruga, M., Medvidovic-Kosanovic, M., NovaK, I. (2007). Anthocyanin content and antioxidant activity of various red fruit juices. Deutsche Lebensmittel-Rundschau. 103. 59-64.

KAPPEL, F., (1991). Partitioning of above-ground dry matter in 'Lambert' sweet cherry trees with or without fruit. Journal of the American Society for Horticultural Science. 116. 201-205.

Kim, D. O., HeO, H. J., Kim, Y. J., YANG, H. S., LEE, C. Y. (2005). Sweet and sour cherry phenolics and their protective effects on neuronal cells. Journal of Agricultural Food Chemistry. 53. 9921-9927.

MI 08-1741/1-88: Mezőgazdasági Müszaki Irányelvek.

MSZ ISO 750:2001: Magyar Szabványügyi Testület.

Muskovics, G., Felföldi, J., Kovács, E., Perlaki, R., Kállay, T. (2006). Changes in physical properties during fruit ripening of Hungarian sweet cherry (Prunus avium L.) cultivars. Postharvest Biology \& Technology. 40. 56-63.

Nagy, P. T., Thurzó, S., Drén, G., SzAbó, Z., SoltéSz, M., NyÉKi, J. (2007). Comparative study of effects of a complex fertilizer and a biostimulator on macroelement content of leaf and fruit quality on sweet cherry (Prunus avium). International Journal of Horticultural Science. 13. (3) 91-94.

NAGY, P. T., NYÉKI, J., SZABÓ, Z. (2010). Nutritional aspects of producing fruits organically. International Journal of Horticultural Science. 16. (3) 69-74.

San-Martino, L., Manavella, F.A., Arribillaga-García, D., Salato, G., (2008). Phenology and fruit quality of nine sweet cherry (Prunus avium L.) cultivars in South Patagonia. Acta Horticulturae. 795. 841-847.

SKALAR (1996). Handbook of Manual San Plus analyzer, skalar methods.

SimON, G., HROTKÓ, K., MAGYAR, L. (2004). Fruit quality of sweet cherry cultivars grafted on four different rootstocks. International Journal of Horticultural Science. 10. (3) 59-62. 
SwietLiK, J. (2004). Production of stone fruit in Poland after integration with European Union. In: National Conference on New Technology in Production of Plum, Sour Cherry and Sweet Cherry Trees (ed. T. LIGOCKA). Skierniewice: ISK Press. pp. 5-13.

SZABÓ, Z., FARKAS, E., SoltÉSZ, M., FiesZl, C., BALÁZS, G., NyÉKI, J. (2011). New sweet cherry cultivars in intensive plantings. International Journal of Horticultural Science. 17. (1-2) 13-16.

USENIK, V., KASTELEC, D., STAMPAR, F. (2005). Physicochemical changes of sweet cherry fruits related to application of gibberalic acid. Food Chemistry. 90. 663-671.

WANG, H., CAO, G., PRIOR, R. L. (1997). Oxygen radical absorbing capacity of anthocyanins. Journal of Agricultural \& Food Chemistry. 45. 304-309.

\title{
Results of fertilizer experiments on yield and fruit quality of sweet cherry trees
}

\author{
*1'́. Csihon, ${ }^{1}$ I. GondA, ${ }^{2}$ M. Orosz-Tóth, ${ }^{2}$ S. Kincses, ${ }^{1,3}$ I. Holb \\ ${ }^{1}$ Institute of Horticulture, Faculty of Agricultural and Food Sciences and Environmental \\ Management, University of Debrecen, Debrecen \\ ${ }^{2}$ Institute of Agricultural Chemistry and Soil Science, Faculty of Agricultural and Food \\ Sciences and Environmental Management, University of Debrecen, Debrecen \\ ${ }^{3}$ Hungarian Academy of Sciences, Centre for Agricultural Researches, Department of \\ Plant Pathology, 1022 Budapest, Herman Ottó street 15.
}

\section{Summary}

Plant nutrition significantly influences yield and fruit quality in fruit orchards. In this three-year study (2016-2018), different fertilizer treatments were compared in an intensive sweet cherry orchard. Trees of cultivar 'Carmen' were grafted on Prunus mahaleb 'Cema' rootstock, and were trained to free spindle. For NP, NPK and NPKMg treatments, yield ranged between 11.8 and $16.6 \mathrm{~kg} /$ tree in the three years, while the yield was $9.1 \mathrm{~kg} /$ tree on the control trees. Crop load (fruit amount calculated to the trunk thickness) was $151-166 \mathrm{~g} \mathrm{~cm}^{-2}$ for fertilized trees, while it was $120 \mathrm{~g} \mathrm{~cm}^{-2}$ on the untreated trees. Fruit sizes of fertilized trees reached $30 \mathrm{~mm}$ in 2018, while the fruit sizes of control trees were smaller with $2.5 \mathrm{~mm}$. Water-soluble dry matter content (\%) of the fertilized trees was lower in 2016 and 2017, but higher in 2018 compared to the control plots. In 2017 and 2018, fertilizer treatments resulted in an increase of the content of phosphorus (16-70\%), potassium (4-22\%) and magnesium (12-43\%) in the fruits compared to control plots.

Keywords: sweet cherry, yield, fruit quality, nutrient management 
Tables and Figures

Table 1: Soil parameters of the experimental orchard (Debrecen-Pallag, 2016);

(1) Humus content (2) "Arany" number of heaviness

Table 2: Applied fertilizer treatments (Debrecen-Pallag, 2016-2018)

Table 3: Application time of the fertilizers (Debrecen-Pallag, 2016-2018); (1) Date of fertilizing (2) Supplied elements

Table 4: Effect of the treatments on the yield (Debrecen-Pallag, 2016-2018); (1) Yield (kg/tree) (2) Specific yield $\left(\mathrm{g} \mathrm{cm}^{-2}\right)$ (3) Average of three years

Table 5: Effect of the treatments on the nutritional value of the fruits (Debrecen-Pallag, 2016-2018) (1) Dry matter content (2) Acid content

Figure 1: Effect of the treatments on the fruit size (Debrecen-Pallag, 2016-2018); (1) Fruit size (mm) (2) Treatments

Open Access nyilatkozat: A cikk a Creative Commons Attribution 4.0 International License (https://creativecommons.org/licenses/by/4.0) feltételei szerint publikált Open Access közlemény, melynek szellemében a cikk bármilyen médiumban szabadon felhasználható, megosztható és újraközölhető, feltéve, hogy az eredeti szerző és a közlés helye, illetve a CC License linkje és az esetlegesen végrehajtott módosítások feltüntetésre kerülnek. (SID_1) 